ひずみ硬化および塑性領域長を考慮した弾塑性梁要素に関する一考察 一単調載荷の場合一

\title{
A STUDY ON ELASTO-PLASTIC BEAM ELEMENT CONSIDERED PLASTIC HARDENING AND PLASTIC REGION SIZE \\ -In case of monotonic loading-
}

\author{
元結 正次郎*，白 奇 烈**，金子 健 作** \\ Shojiro MOTOYUI, Ki Youl BAEK and Kensaku KANEKO
}

\begin{abstract}
In analyzing structures composed of many members, the plastic hinge method or multi-spring model is applied to simulate the elastoplastic behavior of each member. The plastic hinge method is convenient to analyze the elastoplastic behavior. The method is sometimes applied to the elastoplastic problem with hardening, but it can not evaluate to expansion of the plastic region. This is because the consideration of plastic region is contradictory to the basic concept of the plastic hinge method. In comparison, the standard FEM enables us to solve those problems but it is very costly method. So in this paper, we suggest a convenient analytical method for the beams consists of two flanges with plastic hardening property. The numerical results prove the validity and the effectiveness of the present method through the comparisons with results by the standard FEM
\end{abstract}

\section{Keywords: elastoplastic-beam element, hardening, plastic region size, thermodynamics, plastic dissipation} 弾塑性梁要素、ひずみ硬化、塑性領域長、第力学、塑性散逸

\section{1. .はじめに}

骨組構造の弾塑性挙動を効率よくシミュレーションするための手 法として塑性ヒンジ法やマルチスプリングモデルが挙げられる。こ の手法は簡便さが故に研究·設計に広く用いられており、主として、 梁部材には単純塑性ヒンジモデルが、柱やトラス部材など軸力の影 響が大きい部材には一般化塑性ヒンジモデルが使われている。また マルチスプリングモデルは、スプリング長の設定など問題は含んで いるものの局部座屈などへの拡張性なども評価されている.1)。

一般に実在の鉄骨部材には材料特性に起因するひずみ硬化現象が 存在する。このひずみ硬化現象を有する部材を解析する場合にも塑 性ヒンジモデルが適用される場合がある。この場合には、硬化則と してPrager 則に基づく移動硬化則を用いた定式化による解析手法が 適用される。しかしながら、ひずみ硬化を考える場合、特に、軸力 が大きい場合には、塑性領域が材軸方向に進展することは周知のこ とであり、塑性領域は大きさを持たないものとして本来定式化され る塑性ヒンジモデルを適用することは基本概念上の矛盾が生じる。 マルチスプリングモデルも塑性領域の進展を系統的に考慮すること は困難である (付録参照)。このような塑性領域の広がりを考慮する 場合には、部材内部に参照点あるいは参照断面において塑性化を考 慮した応力あるいは断面力を算出し、これを数值積分することによ り部材の材端力ベクトルおよび接線剛性マトリクスを求める方法が
古くから採用されている。ファイバーモデルもこの1つである。こ れらの方法は精度的な問題は少ないが、かなりの計算時間を必要と するために、実在の建物全体を解析するための手法とは言い難い。

そこで、本論文では、Fig.1 に示すような断面を 2 フランジモデル とする柱梁部材を対象として、塑性領域の大きさを評価する実用的 解法を提案する。まず、2 節にて、フランジの特性が与えられた場 合の弾塑性問題を文献 6 で示したトラス梁の連続体置換モデルと同 様の方法により記述する。局所的な硬化現象が Prager 則に従う場合 であっても、この局所的硬化の材端力に対する影響は Prager 則とし て表すことはできないことを示す。次に、2 節で得られた基礎式を 基に塑性領域長が梁の降伏後の挙動に及ぼす影響について示した後、 実用的力学モデルおよびこれの解法について示す。

なお、本論文では、記述の簡略化のために、 $J$ 節点にはモーメン 卜は作用しない $\left(M_{J}=0\right)$ もととし、考えるべき材端力空間を $\left(N, M_{I}\right.$ $(=M)$ 平面とする(Fig.1 参照)。

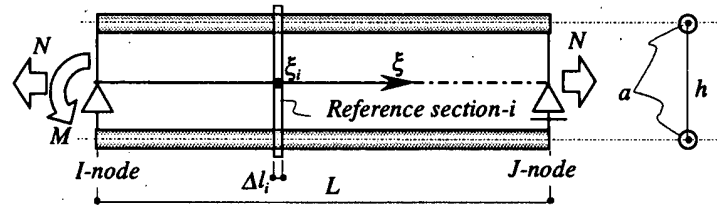

Fig.1 Two-flange model
* 東京工業大学大学院人間環境システム専攻 助教授・工博

** 東京工業大学大学院人間環境システム專攻 大学院生
Assoc. Prof., Dept. of Built Environment, Interdisciplinary Graduate School, Tokyo Institute of Technology, Dr. Eng.

Graduate Student, Dept. of Built Environment, Interdisciplinary Graduate School, Tokyo Institute of Technology 


\section{2. 移動硬化則を含む基磲式の誘導ー2フランジモデルー}

本節では、梁断面を2フランジモデルとした上で、これに関する 基礎式を誘導し、特に、本論文で対象とする問題自体の明確化およ びひずみ硬化の適切な評価方法について明らかにする。なお、せん 断の影響については無視する。

上下フランジの弾性構成則、降伏条件式、塑性流れ則、および硬 化則を次のように表されるものとする。ここでは、硬化則として移 動硬化則のみを考えることとする。

$$
\begin{array}{ll}
n_{i}^{ \pm}=E a\left(\varepsilon_{i}^{ \pm}-\varepsilon_{i}^{p \pm}\right), & \phi^{i \pm}=\frac{\left|n_{i}^{ \pm}-\alpha_{i}^{ \pm}\right|}{n_{Y}}-1 \leq 0 \\
\dot{\varepsilon}_{i}^{p \pm}=\frac{n_{i}^{ \pm}-\alpha_{i}^{ \pm}}{\left|n_{i}^{ \pm}-\alpha_{i}^{ \pm}\right|} \frac{1}{n_{Y}} \dot{\gamma}_{i}^{ \pm}, \quad \dot{\alpha}_{i}^{ \pm}=\frac{n_{i}^{ \pm}-\alpha_{i}^{ \pm}}{\left|n_{i}^{ \pm}-\alpha_{i}^{ \pm}\right|} \frac{E_{T} a}{n_{Y}} \dot{\gamma}_{i}^{ \pm}
\end{array}
$$

ここに、 $n_{i}, \varepsilon_{i}, \varepsilon_{i}^{p}, \alpha_{i}, \gamma_{i}$ はフランジの微小線要素 $i$ における軸力、軸 ひずみ、軸ひずみ塑性成分、移動硬化を表す Back-stress および塑性 進展パラメータであり、 $E, E_{T}, a, n_{Y}$ はヤング係数、硬化係数、フラ ンジ断面積および初期降伏軸力を表す定数である。また、ドットは 時間に対する変化率（速度）を表し、さはフランジ位置（上下など） を表す。このような特性を持つフランジから成る梁の自由エネルギ 一世は以下のように表される ${ }^{4)}$ 。

$$
\Psi=\frac{1}{2}\left[\sum_{i=1}^{n}\left(E a \varepsilon_{i}^{e+2}+E_{T} a \varepsilon_{i}^{\alpha+2}\right) \Delta l_{i}+\frac{1}{2} \sum_{i=1}^{n}\left(E a \varepsilon_{i}^{c^{-2}}+E_{T} a \varepsilon_{i}^{\alpha-2}\right) \Delta l_{i}\right]
$$

ここに、 $\varepsilon_{i}^{e \pm}$ は各フランジ軸ひずみの弾性成分、 $\varepsilon_{i}^{\alpha \pm}$ は Back- stress に対する各フランジ軸ひずみ（以下、硬化ひずみと呼ぶ）であり、n は材軸方向分割数であり、 $\Delta l_{i}$ は分割長さ $(L n ; L$ は材長) である。 なお、本来連続体の場合には $n \rightarrow \infty$ として積分表示にするのが一般 的であるが、論旨を明確にするために本節では有限分割としている。

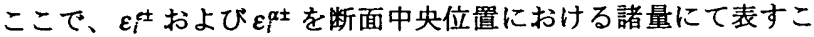
ととし、以下のように表されるものとする。

$$
\begin{gathered}
\varepsilon_{i}^{ \pm \pm}=\varepsilon_{i}^{ \pm}-\varepsilon_{i}^{p \pm}=\left(\varepsilon_{i}^{0} \pm \frac{h}{2} \kappa_{i}\right)-\left(\varepsilon_{i}^{p 0} \pm \frac{h}{2} \kappa_{i}^{p}\right)=\varepsilon_{i}^{0}-\varepsilon_{i}^{p 0} \pm \frac{h}{2}\left(\kappa_{i}-\kappa_{i}^{p}\right)(3 . a) \\
\varepsilon_{i}^{\alpha \pm}=\varepsilon_{i}^{\alpha 0} \pm \frac{h}{2} \kappa_{i}^{\alpha}
\end{gathered}
$$

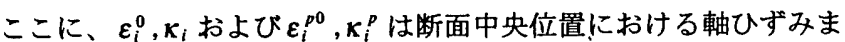
たは曲げひずみの全成分および塑性成分であり、 $\varepsilon_{i}^{\alpha 0}, \kappa_{i}^{\alpha}$ は同硬化 ひずみを示す。 $h$ は梁成である。複号は同順とする。これらを式(2) に代入することにより、次式が得られる。

$$
\begin{aligned}
\Psi & =\frac{1}{2} \sum_{i=1}^{n}\left(E A\left(\varepsilon_{i}^{0}-\varepsilon_{i}^{p 0}\right)^{2}+E I\left(\kappa_{i}-\kappa_{i}^{p}\right)^{2}\right) \Delta l_{i} \\
& +\frac{1}{2} \sum_{i=1}^{n}\left(E_{T} A \varepsilon_{i}^{\alpha 0^{2}}+E_{T} I \kappa_{i}^{\alpha^{2}}\right) \Delta l_{i} \\
A & =2 a, I=a h^{2} / 2
\end{aligned}
$$

ここに、 $A, I$ は梁としての断面積および断面 2 次モーメントである。 上式の第 1 項は弾性エネルギーであるから、次のように書きなおす ことができる。

$$
\begin{gathered}
\Psi=\frac{1}{2}\left(u-u_{p}\right)^{T} k^{e}\left(u-u_{p}\right)+\frac{1}{2} \sum_{i=1}^{n}\left(E_{T} A \varepsilon_{i}^{\alpha 0^{2}}+E_{T} I \kappa_{i}^{\alpha^{2}}\right) \Delta l_{i} \\
u^{T}=\left\langle\begin{array}{ll}
u & \theta
\end{array}, \quad u_{p}^{T}=\left\langle u_{p} \theta_{p}\right\rangle\right. \\
k^{e}=\left[\begin{array}{cc}
k^{N} & 0 \\
0 & k^{M}
\end{array}\right], \quad k^{N}=\frac{E A}{L}, \quad k^{M}=\frac{3 E I}{L}
\end{gathered}
$$

ここに、 $\boldsymbol{u}, \boldsymbol{u}_{p}$ は節点(相対)変位ベクトルの全成分および塑性成分、 $\boldsymbol{k}$ は梁の判性マトリクス（弾性構成則に相当）である。

ここで、材端カベクトル $f^{T}=\langle N M\rangle$ を考え、上記の自由エネルギ
一の変化率を Clausius-Duhem $の$ 不等式 $-\dot{\Psi}+f^{T} \dot{u} \geq 0$ に代入する。

$$
\begin{aligned}
& \left\{f-k^{e}\left(u-u_{p}\right)\right\}^{T} \dot{u} \\
& +\left(u-u_{p}\right)^{T} k^{e} \dot{u}_{p}-\left[\sum_{i \in a c t i v e}\left(E_{T} A \varepsilon_{i}^{\alpha 0} \dot{\varepsilon}_{i}^{\alpha 0}+E_{T} I \kappa_{i}^{\alpha} \dot{\boldsymbol{k}}_{i}^{\alpha}\right) \Delta l_{i}\right] \geq 0
\end{aligned}
$$

上記の総和記号は塑性負荷状態にある区間の総和を表す。この不等 式が任意の変位速度について成り立つための条件として次式が得ら れる。

$$
\begin{aligned}
& f=k^{e}\left(u-u_{p}\right) \\
& \Gamma=f^{T} \dot{u}_{p}+\sum_{i \in a c t i v e}\left(N_{i}^{\alpha} \dot{\varepsilon}_{i}^{\alpha 0}+M_{i}^{\alpha} \dot{\kappa}_{i}^{\alpha}\right) \Delta l_{i} \geq 0
\end{aligned}
$$$$
\text { ここに、 } N_{i}^{\alpha}=-E_{T} A \varepsilon_{i}^{\alpha 0}, \quad M_{f}^{\alpha}=-E_{T} I \kappa_{f}^{\alpha}
$$

式(7.b)の表現から、f， $N_{i}^{\alpha}, M_{i}^{\alpha}$ は $\boldsymbol{u}_{p}, \varepsilon_{i}^{\alpha 0}, \boldsymbol{\kappa}_{i}^{\alpha}$ に対する熱力学的力に 相当することが理解される。個材の軸力および Back-stress は参照断 面 $i$ における軸力 $N_{i}$, 曲げモーメント $M_{i}$ および $N_{i}^{\alpha}, M_{i}^{\alpha}$ により、

$$
n_{i}^{ \pm}=\frac{N_{i}}{2} \pm \frac{M_{i}}{h}, \quad \alpha_{i}^{ \pm}=\frac{N_{i}^{\alpha}}{2} \pm \frac{M_{i}^{\alpha}}{h}
$$

と表され、これを式(1.b)の個材の降伏条件式に代入する。

$$
\phi^{i}=\left|\frac{N_{i}-N_{i}^{\alpha}}{N_{Y}} \pm \frac{M_{i}-M_{i}^{\alpha}}{M_{p}}\right|-1=\left|\frac{N_{i}-N_{i}^{\alpha}}{N_{Y}}\right|+\left|\frac{M_{i}-M_{i}^{\alpha}}{M_{p}}\right|-1 \leq 0
$$

ここに、 $N_{Y}, M_{p}$ は軸力,曲げモーメントに対する全塑性耐力であり、

$$
N_{Y}=2 n_{Y}, \quad M_{p}=n_{Y} h
$$

である。式(9)が各参照断面での断面力に対する降伏条件式である。 さらに、参照断面位置を科とすれば、材端力と断面力の関係は、

$$
N_{i}=N, \quad M_{i}=\left(1-\xi_{i}\right) M, \quad \xi_{i}=[0,1]
$$

であるから、これを用いて、材端力に対する降伏条件式を求めると、

$$
\phi^{i}=\left|\frac{N-N_{i}^{\alpha}}{N_{Y}}\right|+\left|\frac{\left(1-\xi_{i}\right) M-M_{i}^{\alpha}}{M_{P}}\right|-1 \leq 0
$$

となる。さらに、 $N_{i}^{\alpha}, M_{i}^{\alpha}$ についも式(11)のような表現が可能で あるものとして、式(12)を次のように書き值す。

$$
\begin{gathered}
\phi^{i}=\left|\frac{N-N_{i}^{A}}{N_{Y}}\right|+\left(1-\xi_{i}\right)\left|\frac{M-M_{i}^{A}}{M_{p}}\right|-1 \leq 0 \\
N_{i}^{A}=N_{i}^{\alpha}, \quad M_{i}^{A}=\frac{M_{i}^{\alpha}}{\left(1-\xi_{i}\right)}
\end{gathered}
$$

処女材料時における式(13)を $N, M$ 空間上に図示したものが Fig.2 である。図中には $\xi_{i}$ の值として 0.25 刻みで記してあり、実際には灰 色にて示す領域には無数の降伏関数が存在することとなる。この図

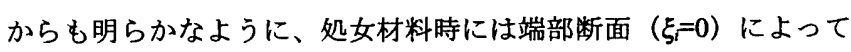
規定される条件のみが active であり、これ以外の条件は、咒長な条
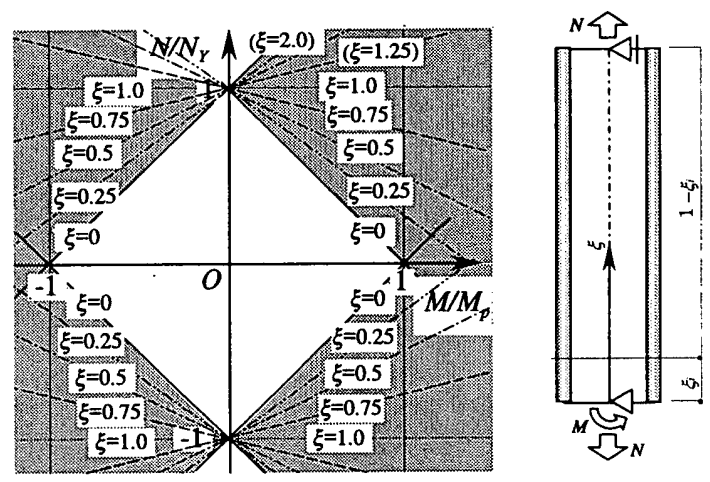

Fig. 2 Yield function in $N-M$ space 
条件にすぎないが、材端力がひずみ硬化により当初の許容空間を逸 脱し灰色で示した領域を推移する段階で順次 active となる。

次に、塑性流れ則を求めるために、最大塑性散逸の原理が成り立 つものとして次のラグランジアンを考える。

$$
\begin{aligned}
L & =-\Gamma+\sum_{i \in a c t i v e} \Delta l_{i} \lambda_{p i} \phi^{i} \\
& =-N \dot{u}_{p}-M \dot{\theta}_{p}-\sum_{i \in a c t i v e}\left(N_{i}^{A} \dot{\varepsilon}_{i}^{\alpha 0}+\left(1-\xi_{i}\right) M_{i}^{A} \dot{\kappa}_{i}^{\alpha}\right) \Delta l_{i} \\
& +\sum_{i \in a c t i v e} \Delta l_{i} \lambda_{p i}\left[\left|\frac{N-N_{i}^{A}}{N_{Y}}\right|+\left(1-\xi_{i}\right)\left|\frac{M-M_{i}^{A}}{M_{p}}\right|-1\right]
\end{aligned}
$$

ここで、ラグランジェ乗数 $\lambda_{p i}$ は単位長さ当たりの塑性進展パラメー 夕速度を意味する。これより、 $\partial L / \partial N=0, \partial L / \partial M=0$ を計算するこ とで、塑性流れ則が次のように求められる。

$$
\begin{aligned}
& \dot{u}_{p}=\sum_{i \in e c t i v e} \frac{\partial \phi^{\prime}}{\partial N}=\sum_{i \in \text { active }} \frac{\operatorname{sgn}\left(\tilde{N}_{i}\right)}{N_{Y}} \Delta l_{i} \dot{\lambda}_{p i} \\
& \dot{\theta}_{p}=\sum_{i \in \text { active }} \frac{\partial \phi^{i}}{\partial M}=\sum_{i \in \text { active }} \frac{\left(1-\xi_{i}\right) \operatorname{sgn}\left(\tilde{M}_{i}\right)}{M_{p}} \Delta l_{i} \dot{\lambda}_{p i}
\end{aligned}
$$

ここに、 $\operatorname{sgn}(x)$ は符号関数 $[=1 ; x>0,=-1 ; x<0,=0 ; x=0]$ を意味し、 $\tilde{N}_{i}, \tilde{M}_{i}$ は有効応力 $\left(\tilde{N}_{i}=N-N_{i}^{A}, \tilde{M}_{i}=M-M_{i}^{A}\right)$ である。硬化ひず みについても同様に、

$$
\begin{aligned}
& \frac{\partial L}{\partial N_{i}^{\alpha}}=0 ; \quad \dot{\varepsilon}_{i}^{\alpha 0}=-\frac{\operatorname{sgn}\left(\tilde{N}_{i}\right)_{\dot{\lambda}_{p i}}}{N_{Y}} \\
& \frac{\partial L}{\partial M^{\alpha}}=0 ; \quad \dot{\kappa}_{i}^{\alpha}=-\frac{\operatorname{sgn}\left(\tilde{M}_{i}\right)_{\dot{\lambda}_{p i}}}{M_{p}}
\end{aligned}
$$

式(16.a,b)は Koiter 流の Associate flow 則と一致している。ここで、 上記の表現が熱力学第 2 法則を満足することを確認するために、式 (7.b)の散逸項に上式をそれぞれ代入する。

$$
\Gamma=\sum_{i \in \text { active }}\left[\left|\frac{N-N_{i} \hat{A}}{N_{Y}}\right|+\left(1-\xi_{i}\right)\left|\frac{M-M_{i} \hat{i}}{M_{p}}\right| \Delta l_{i} \dot{\lambda}_{p i}=\sum_{i \in a c t i v e} \Delta l_{i} \dot{\lambda}_{p i}\right.
$$

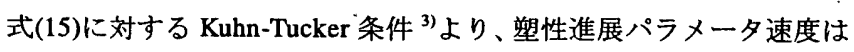
いずれも正または零でなければならないので、上式の值は正または 零であり、このことは熱力学第 2 法則を満足することを意味する。 また、塑性進展パラメータの総和自体がエネルギーの散逸量を意味 していることが解る。

また、硬化則は、式(14)を速度表現とじた式に式(7.c)および式(17) を代入することにより、

$$
\begin{aligned}
& \dot{N}_{i}^{A}=\dot{N}_{i}^{\alpha}=\frac{E_{T} A \operatorname{sgn}\left(\tilde{N}_{i}\right)}{N_{Y}} \dot{\lambda}_{p i} \\
& \dot{M}_{i}^{A}=\frac{\dot{M}_{i}^{\alpha}}{\left(1-\xi_{i}\right)}=\frac{1}{\left(1-\xi_{i}\right)} \frac{E_{T} I \operatorname{sgn}\left(\tilde{M}_{i}\right)_{\lambda_{p i}}}{M_{p}}
\end{aligned}
$$
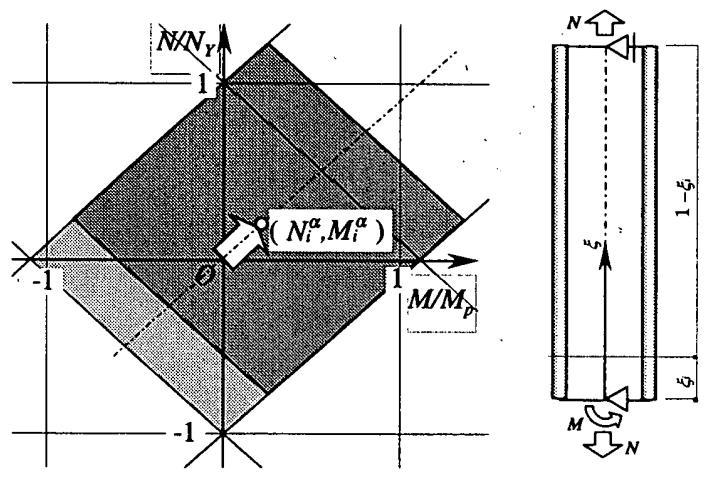

Fig.3 Hardening rule to the present model
となる。また、 $\frac{\partial \phi^{i}}{\partial N}=-\frac{\partial \phi^{i}}{\partial N_{i}^{i}}, \frac{\partial \phi^{i}}{\partial M}=-\frac{\partial \phi^{i}}{\partial M_{i}^{A}}$ なる関係を利用し、上 式を次のように書きなおす。

$$
\begin{gathered}
\dot{f}_{i}^{\alpha}=k^{\alpha} \frac{\partial \phi^{i}}{\partial f} \dot{\lambda}_{p i} \\
\dot{f}_{i}^{\alpha}=\left\{\begin{array}{c}
\dot{N}_{i}^{\alpha} \\
\dot{M}_{i}^{\alpha}
\end{array}\right\}, \quad k^{\alpha}=\left[\begin{array}{cc}
E_{r} A & 0 \\
0 & \frac{E_{T} I}{\left(1-\xi_{i}\right)^{2}}
\end{array}\right], \quad \frac{\partial \phi^{i}}{\partial f}=\left\{\begin{array}{l}
\frac{\partial \phi^{i}}{\partial N} \\
\frac{\partial \phi^{i}}{\partial M}
\end{array}\right\}
\end{gathered}
$$

$(20 . b, c, d)$

この硬化則の無次元化された材端力空間上での意味を明らかにする ために、式(19)を次式のように変換する。

$$
\left\{\begin{array}{l}
\dot{N}_{i}^{A} / N_{Y} \\
\dot{M}_{i}^{A} / M_{p}
\end{array}\right\}=\frac{E_{T} a}{2 n_{Y}{ }^{2}}\left\{\begin{array}{l}
\operatorname{sgn}\left(\tilde{N}_{i}\right) \\
\frac{\operatorname{sgn}\left(\tilde{M}_{i}\right)}{\left(1-\xi_{i}\right)}
\end{array}\right\} \dot{\lambda}_{p t}
$$

Fig.3 は、ある断面位置を例として、材端力 $(N, M)$ が第 1 象元にある 場合について式(21)を記述したものである。本モデルの材端力に対 する硬化則は、 $I$ 節点端部 $(\xi=0) に よ り$ 規定される降伏条件に関して は Prager の移動硬化則と一票するものの ${ }^{2)} 、$ 一般部 $(\xi \neq 0) k$ 関して は Fig.3に示すように、Prager 則とは異なり、Back-stressは、対をな す降伏線に平行な方向に生ずることを示している。これは、表現は 異なるが文献 6 で対象としたワーレントラス梁の結果と一致する。

また、各断面における塑性進展パラメータ速度は、塑性負荷条件 $\dot{\phi}^{i}=0$ より、 $\dot{\phi}^{i}=\frac{\partial \phi^{i}}{\partial f} \dot{f}+\frac{\partial \phi^{i}}{\partial f_{i}^{\alpha}} \dot{f}_{i}^{\alpha}=0 か^{\circ}$ active な条件数だけ成り立 たなければならないことから求められる。ここで、応力速度は、式 (7.a),式(16)から、

$$
\dot{f}=k_{e}\left(\dot{u}-\sum_{i \in a c t i v e} \frac{\partial \phi^{\prime}}{\partial f} \Delta l_{i} \dot{\lambda}_{p i}\right)
$$

となるので、これらを上記の負荷条件に代入することにより、次の 塑性進展パラメータに関する連立方程式が得られる。

$$
\sum_{i \in \text { active }}\left(\frac{\partial \phi^{j}}{\partial f} k^{e} \frac{\partial \phi^{i}}{\partial f}+\frac{1}{\Delta l_{i}} \frac{\partial \phi^{j}}{\partial f} k^{\alpha} \frac{\partial \phi^{i}}{\partial f} \delta_{i}^{j}\right) \Delta l_{i} \dot{\lambda}_{p i}=\frac{\partial \phi^{j}}{\partial f} k_{e} \dot{u}
$$

ここに、 $\delta_{i}^{j}$ はクロネッカーデルタである。硬化を考慮した場合には 上式左辺の保数マトリクスが正值となること、およひ、、有限要素に おいて通常用いられる数值積分点にて弾塑性判定を行う方法やファ イバーモデルと比べた本手法の特徵は、既に文献 6 にて示したとお りである。

\section{3、望性領找の広がりを考慮した実用的力学モデルの構築}

\section{1 式(16)および式(23)の近似表現}

前節では、2 フランジモデルに関する基礎式を求めた。しかしな がら、連続体の梁の場合には前述したように、塑性進展パラメータ

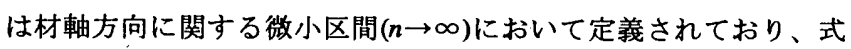
(23)の係数マトリクスは無限の次数を有する正方マトリクスとなる。 これを回避する最も単純な方法は $n$ を実質的に問題のない程度の分 割数とする方法（文献 6 で示した手法の直接的拡張）も考えられる が、ここでは、より簡便な手法として各微小区間における塑性進展 パラメータ分布を仮定する実用的手法を提示する。ここで、用いる 仮定をBox 1 に示す。

仮定 A,B,C に従う梁内部への塑性化の進展の一例を示せば、Fig.4 のように模式的に表すことができる(付録 Fig.A-5 参照)。この例は、 
Box 1 Assumption

〈仮定 A〉時刻 $t$ における塑性領域の範囲を $\xi=\left[\xi_{s}(=0), \xi_{e}\right]$ とし て各断面位置での降伏条件式に対する塑性進展パラ メータ速度が、独立ではなく、次のように表される ものとする。

$$
\dot{\lambda}_{p}(\xi)=\frac{\xi}{\xi_{e}} \dot{\lambda}_{p e}+\frac{\xi_{e}-\xi}{\xi_{e}} \dot{\lambda}_{p s}
$$

〈仮定 B〉塑性進展パラメータの分布もまた同様に塑性領域内 において線形に分布するものとする。

$$
\lambda_{p}(\xi)=\frac{\xi^{\prime}}{\xi_{e}} \lambda_{p e}+\frac{\xi_{e}-\xi^{\prime}}{\xi_{e}} \lambda_{p s}
$$

〈仮定 C〉このときの $\xi_{e}$ が取り得る範囲は $0 \leq \xi_{e} \leq 2$ とする。

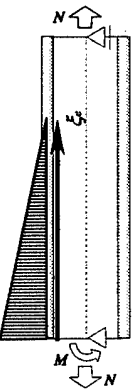

(a)

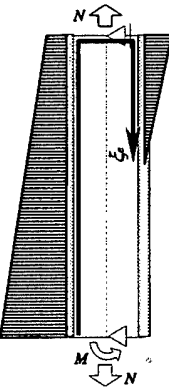

(b)

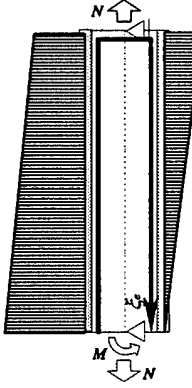

(c)

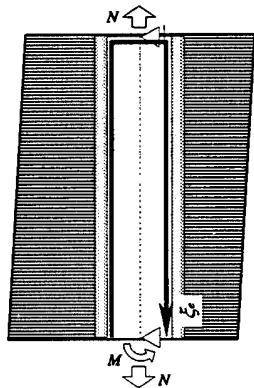

(d)
Fig.4 Progressing of plastic region

(a) 塑性領域が左フランジにて発生し成長する状態 $\left(0 \leq \xi_{e} \leq 1\right)$

(b) 塑性領域が右フランジへと進展する状態 $\left(1 \leq \xi_{e}<2\right)$

(c) 塑性領域が右フランジ全域に達する状態 $\left(\xi_{e}=2\right)$

(d) 塑性領域は変化せず塑性負荷が続く状態 $\left(\xi_{e}=2\right)$

へと移行する様子を示している。

これらの仮定に従う場合の塑性流れ則について計算する。式(16) の塑性流れ則は、参照断面区間を微小とすることにより次のように 表される。

$$
\dot{u}_{p}=\lim _{\Delta l \rightarrow 0 \text { i } \in \text { active }} \frac{\partial \phi^{i}}{\partial f} \Delta l_{i} \dot{\lambda}_{p i}=\int_{0}^{\xi e} \frac{\partial \phi^{i}}{\partial f} \dot{\lambda}_{p i} L d \xi
$$

ここで、仮定 A に従い、式(24)を式(26)に代入し、積分することに より、節点変位の塑性成分は次のように表される。

$$
\begin{aligned}
& \dot{u}_{p}=\left\{\begin{array}{c}
\frac{\operatorname{sgn}(\tilde{N})}{N_{Y}} \\
\left(1-\frac{1}{2} \xi_{c}\right) \frac{\operatorname{sgn}(\tilde{M})}{M_{p}}
\end{array}\right\} \dot{\Lambda}_{p 0}+\left\{\begin{array}{c}
0 \\
\xi_{e} \frac{\operatorname{sgn}(\tilde{M})}{M_{p}}
\end{array}\right\} \dot{\Lambda}_{p 1} \\
& \dot{\Lambda}_{p 0}=\frac{L \xi_{c}}{2}\left(\dot{\lambda}_{p s}+\dot{\lambda}_{p e}\right), \quad \dot{\Lambda}_{p 1}=\frac{L \xi_{e}}{12}\left(\dot{\lambda}_{p s}-\dot{\lambda}_{p e}\right)
\end{aligned}
$$

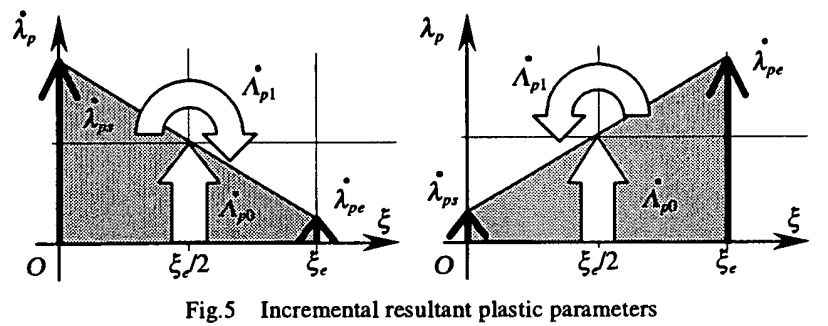

これが塑性領域長を考慮した場合の塑性流れ則である。同様な展開 により、式(23)は次のように表される。

$$
\begin{gathered}
{\left[\frac{k^{N}}{N_{Y}{ }^{2}}+\left(1-\frac{1}{2} \xi_{e}\right)^{2} \frac{k^{M}}{M_{p}{ }^{2}}+\frac{K^{T}}{2 \xi_{e}}\right] \dot{\Lambda}_{p 0}+\left[\left(1-\frac{1}{2} \xi_{e}\right) \xi_{e} \frac{k^{M}}{M_{p}{ }^{2}}\right]_{p 1}} \\
=\operatorname{sgn}(\tilde{N}) \frac{k^{N}}{N_{Y}} \dot{U}+\left(1-\frac{1}{2} \xi_{e}\right) \operatorname{sgn}(\tilde{M}) \frac{k^{M}}{M_{p}} \dot{\theta} \\
\left(1-\frac{1}{2} \xi_{e}\right) \xi_{e} \frac{k^{M}}{M_{p}{ }^{2}} \dot{\Lambda}_{p 0}+\left[\xi_{e}{ }^{2} \frac{k^{M}}{M_{p}{ }^{2}}+\frac{12 K^{T}}{\xi_{e}}\right]_{p 1} \\
=\xi_{e} \operatorname{sgn}(\tilde{M}) \frac{k^{M}}{M_{p} \dot{\theta}} \\
K^{T}=\frac{E_{T} A}{N_{Y}{ }^{2} L}+\frac{E_{T} I}{M_{p}{ }^{2} L}
\end{gathered}
$$

式(27)および式(29)から以下のことが理解される。

・式(27)および式(29)から、完全弾塑性体を対象とした場合には、端 部の塑性化により規定されるために $\xi_{e} \rightarrow 0$ となり、通常の塑性七 ンジ法におけるそれぞれの表現と一致する。

・式(27)から、塑性領域長を考慮することにより、梁要素の節点変 位速度の塑性回転成分が低減される。

・式(29)から、端部が降伏した直後は $\xi_{e}=0$ であり、見かけ上の硬化 係数が無限大となり、梁としての挙動は弾性的である。

また、 $\dot{\Lambda}_{p 0}, \dot{\Lambda}_{p 1}$ は、Fig.5 に示すように時刻 $t$ における塑性領域に おける塑性進展パラメータの総和と 1 次変化率を意味するものであ る。この $\dot{\Lambda}_{p 0}$ の意味および式(18)より、熱力学第 2 法則を満足する ための条件として、

$$
\dot{\Lambda}_{p 0} \geq 0
$$

のみが要求され、 $\dot{\Lambda}_{p 1}$ は任意の値を取り得る。

なお、Fig.4において状態(b)以降の参照断面内の両フランジに塑 性領域が形成された場合（ $\xi_{e}>1 ） に$ に、断面力に関する降伏条件式 (式(9)) 中の (曲げ) モーメントの符号を考虑した次の 2 式を本来 考える必要がある。

$$
\phi^{i}=\left|\frac{N_{i}-N_{i}^{\alpha}}{N_{Y}}\right| \pm \frac{M_{i}-M_{i}^{\alpha}}{M_{p}}-1 \leq 0
$$

このような場合でも仮定 C の導入により、2 式を考虑したこととな り、式(27),(29)は成り立つことに注意する。例えば、純引張（圧縮） 状態では、 $\xi_{e}=2$ かつ $\tilde{M}=0$ であるから、式(29.a)は、

$$
\left[\frac{k^{N}}{N_{Y}{ }^{2}}+\frac{K^{T}}{2 \xi_{e}}\right] i_{p 0}=\operatorname{sgn}(\tilde{N}) \frac{k^{N}}{N_{Y}} \dot{u}
$$

となり、これから $\dot{\Lambda}_{p 0}$ を求め、式(27)に代入し、さらに、式(4.b), (5.f), (10)および式(30)を代入することにより、

$$
\dot{u}_{p}=\frac{k^{N}}{N_{Y}{ }^{2}}\left[\frac{k^{N}}{N_{Y}{ }^{2}}+\frac{K^{T}}{2}\right]^{-1} \dot{u}=\frac{E}{E+E_{T}} \dot{u}
$$

となる。これは 1 軸応力状態時の表現に他ならない。このことは、 Fig.2における引〉1 の降伏線が逆符号のモーメントとした条件に一 致することからも理解される。ただし、Fig.4とは異なり、塑性領域 が分断されて生じるような場合には、軸力が零または零近傍の場合 には、軸力の符号を考慮した次の 2 式を考慮しなければならない。

$$
\phi^{i}= \pm \frac{N_{i}-N_{i}^{\alpha}}{N_{Y}}+\left|\frac{M_{i}-M_{i}^{\alpha}}{M_{p}}\right|-1 \leq 0
$$

なお、本論文ではこのような場合については対象外とする。 


\section{2 等価モデルの設定および基䃈式の誘導}

ここでは整合性を有する実用的解法を提示するために、式(27)お よび式(29)と同様な表現を得るための梁の自由エネルギー表現およ び降伏関数表現（等価モデルと称する）を設定し、これらを用いて ひずみ硬化および塑性領域の大きさを考虑した場合の各基礎式の誘 導を行う。まず、等価モデルの自由エネルギーとして次式を考える こととする。

$$
\Psi=\frac{1}{2}\left(u-u_{p}\right)^{T} k^{e}\left(u-u_{p}\right)+H\left(u_{C}, \theta_{C}, \theta_{D}\right)
$$

ここに、 $u_{C}, \theta_{C}, \theta_{D}$ は硬化性状を表す変数である。 2 節の展開同様、 この変化率を Clausius-Duhem の不等式 $-\dot{\Psi}+\boldsymbol{f}^{T} \dot{u} \geq 0$ に代入する。

$$
\begin{aligned}
\left\{f-k^{e}\right. & \left.\left(u-u_{p}\right)\right\} \cdot \dot{u}+\left(u-u_{p}\right) \cdot k^{e} \dot{u}_{p} \\
& -\frac{\partial H}{\partial u_{C}} \dot{u}_{C}-\frac{\partial H}{\partial \theta_{C}} \dot{\theta_{C}}-\frac{\partial H}{\partial \theta_{D}} \dot{\theta_{D}} \geq 0
\end{aligned}
$$

この不等式が任意の変位速度について成り立つための条件として次 式が得られる。

$$
\begin{aligned}
f & =k^{c}\left(u-u_{p}\right) \\
\Gamma & =f \cdot \dot{u}_{p}+N^{c} \dot{u}_{C}+M^{c} \dot{\theta}_{C}+M^{D} \dot{\theta}_{D} \geq 0 \\
こ こ に 、 \quad N^{c} & =-\frac{\partial H}{\partial u_{C}}, M^{c}=-\frac{\partial H}{\partial \theta_{C}}, M^{D}=-\frac{\partial H}{\partial \theta_{D}}
\end{aligned}
$$

さらに、上記の各熱力学的力を用いて、材端力に対する降伏条件 式を以下のように表現する。

$$
\Phi^{c}=\left|\frac{N-N^{c}}{N_{Y}}\right|+\left(1-\frac{1}{2} \xi_{e}\right)\left|\frac{M-M^{c}}{M_{p}}\right|-1 \leq 0
$$

さらに、上式が active な場合に限り次式の制約条件式も考慮する。

$$
F^{D}=\xi_{e}\left|\frac{M-M^{D}}{M_{p}}\right|-\chi=0
$$

ここに、 $N^{c}, M^{c}, M^{D}$ は塑性領域長を考慮したとき材端力に対する等 価な Back-stress であり、 $\chi$ は数值的安定化を図るための定数(う0)で ある。塑性流れ則を求めるために、最大塑性散冕の原理が成り立つ ものとして次のラグランジアンを考える。

$$
\begin{aligned}
L & =-N \dot{u}_{p}-M \dot{\theta}_{p}^{\prime} \\
& -N^{C} \dot{u}_{C}-M^{c} \dot{\theta}_{C}-M^{D} \dot{\theta}_{D}+\dot{\Omega}_{C} \Phi^{C}+\dot{\Omega}_{D} F^{D}
\end{aligned}
$$

これより、塑性流れ則が次のように求められる。

$$
\begin{gathered}
\dot{u}_{p}=\frac{\operatorname{sgn}\left(\tilde{N}^{c}\right)}{N_{Y}} \dot{\Omega}_{C} \\
\dot{\theta}_{p}=\left(1-\frac{1}{2} \xi_{e}\right) \frac{\operatorname{sgn}\left(\tilde{M}^{c}\right)}{M_{p}} \dot{\Omega}_{C}+\xi_{e} \frac{\operatorname{sgn}\left(\tilde{M}^{D}\right)}{M_{p}} \dot{\Omega}_{D} \\
\dot{u}_{C}=-\frac{\operatorname{sgn}\left(\tilde{N}^{c}\right)}{N_{Y}} \dot{\Omega}_{C} \\
\dot{\theta}_{C}=-\left(1-\frac{1}{2} \xi_{e}\right) \frac{\operatorname{sgn}\left(\tilde{M}^{c}\right)}{M_{p}} \dot{\Omega}_{C}, \quad \dot{\theta_{D}}=-\xi_{c} \frac{\operatorname{sgn}\left(\tilde{M}^{D}\right)}{M_{p}} \dot{\Omega}_{D}
\end{gathered}
$$

となる。式(38.a,b)と式(27)を比較することにより、 $\dot{\Omega}_{c}, \dot{\Omega}_{D} か ゙ \dot{\Lambda}_{p 0}$ ， $\dot{\Lambda_{p 1}}$ にそれぞれ対応していることが解る。すなわち、

$$
\dot{\Omega}_{C}=\dot{\Lambda}_{p 0}, \quad \dot{\Omega}_{D}=\dot{\Lambda}_{p 1}
$$

また、式(38)を式(35.b)に代入することにより、散逸項は次のように 表される。

$$
\begin{aligned}
\Gamma & =N \dot{u}_{p}+M \dot{\theta}_{p}+N^{c} \dot{u}_{C}+M^{c} \dot{\theta}_{C}+M^{D} \dot{\theta}_{D} \\
& =\dot{\Omega}_{C}+\chi \dot{\Omega}_{D} \cong \dot{\Omega}_{C}
\end{aligned}
$$

Kuhn-Tucker 条件より $\dot{\Omega}_{c}$ は正でなければならないので、上式の值は 常に正となり、熱力学第 2 法則を満足する。さらに、式(39)から上
式の值は $\dot{\Lambda}_{p 0}$ に等しいことから、散逸項が、3節で対象とした元々 の問題に対して直接誘導された式(18)と等価であることが解る。こ の意味において式(26)および式(29)は、ひずみ硬化および塑性領域の 大きさを適切に評価する表現ということができる。また、式(36.a) から、塑性領域長は、降伏条件式に対するモーメントのみに対する 搪大硬化的影響を有すると言うことができる。

Back-stress に関する硬化則は、各 Back-stress 間の連成がないもの とすれば、式(35.c,d,e)から次のように表される。

$$
\begin{aligned}
& \dot{N}^{c}=-H_{u C C} \dot{u}_{C}=H_{u C C} \frac{\operatorname{sgn}\left(\tilde{N}^{c}\right)}{N_{Y}} \dot{\Omega}_{C} \\
& \dot{M}^{c}=-H_{\theta C C} \dot{\theta_{C}}=H_{\theta C C}\left(1-\frac{1}{2} \xi_{e}\right) \frac{\operatorname{sgn}\left(\tilde{M}^{c}\right)}{M_{p}} \dot{\Omega}_{C} \\
& \dot{M}^{D}=-H_{\theta D D} \dot{\theta}_{D}=H_{\theta D D} \xi_{e} \frac{\operatorname{sgn}(\tilde{M})^{D}}{M_{p}} \dot{\Omega}_{D}
\end{aligned}
$$

ここに、 $H_{u C C}$ 等はそれぞれの Back-stress に対する硬化係数であり、

$$
H_{w C C}=\frac{\partial^{2} H}{\partial u_{C}{ }^{2}}, \quad H_{\theta C C}=\frac{\partial^{2} H}{\partial \theta_{C}{ }^{2}}, \quad H_{\theta D D}=\frac{\partial^{2} H}{\partial \theta_{D}{ }^{2}}
$$

以上の等価モデルに対する塑性流れ則および硬化則を用いて、 $\dot{\Omega}_{C}, \dot{\Omega}_{D}$ に関する連立方程式が式(23)と同様の手順により求められ る。

$$
\begin{aligned}
& {\left[\frac{k^{N}}{N_{\dot{Y}}{ }^{2}}+\left(1-\frac{1}{2} \xi_{e}\right)^{2} \frac{k^{M}}{M_{p}{ }^{2}}+\frac{H_{u C C}}{N_{Y}{ }^{2}}+\left(1-\frac{1}{2} \xi_{e}\right)^{2} \frac{H_{\theta C C}}{M_{p}{ }^{2}}\right] \dot{\Omega}_{C}} \\
& +\left(1-\frac{1}{2} \xi_{e}\right) \xi_{e} \frac{k^{M}}{M_{p}{ }^{2}} \dot{\Omega}_{D}=\frac{\operatorname{sgn}\left(\tilde{N}^{C}\right)}{N_{Y}} k^{N} \dot{u}+\left(1-\frac{1}{2} \xi_{e}\right) \frac{\operatorname{sgn}\left(\tilde{M}^{C}\right)}{M_{p}} k^{M} \dot{\theta}
\end{aligned}
$$

$$
\left[\left(1-\frac{1}{2} \xi_{e}\right) \xi_{e} \frac{k^{M}}{M_{p}{ }^{2}}\right] \dot{\Omega}_{C}+\xi_{e}{ }^{2}\left[\frac{k^{M}}{M_{p}{ }^{2}}+\frac{H_{\theta D D}}{M_{p}{ }^{2}}\right] \dot{\Omega}_{D}=\xi_{e} \frac{\operatorname{sgn}\left(\tilde{M}^{D}\right)}{M_{p}} k^{M} \dot{\theta}
$$

ここで、上記の両式が式(29)と同様な表現となるための硬化係数を 求めると、

$$
\begin{gathered}
H_{w C C}=\frac{E_{T} A}{\beta L \xi_{e}}, \quad \dot{H}_{\theta C C}=\frac{E_{T} I}{\beta\left(1-\frac{1}{2} \xi_{e}\right)^{2} L \xi_{e}} \\
H_{\theta D D}=\frac{12 M_{p}^{2}}{\xi_{e}{ }^{2}}\left(\frac{E_{T} A}{N_{Y}{ }^{2} L}+\frac{E_{T} I}{M_{p}{ }^{2} L}\right)
\end{gathered}
$$

となる。これが等価モデル（式(26)および式(29)）における硬化係数 である。ただし、式(44.a,b)中の $\beta$ は、

$$
\begin{array}{ll}
\xi_{e}<2 \text { の場合 } ; & \beta=2 \\
\xi_{e}=2 \text { の場合 } ; & \beta=1
\end{array}
$$

とする。

次に、等価モデルに対する接線剛性マトリクスを誘導する。式 (35.a)を速度表現にし、これに塑性流れ則を代入することにより、次 式が得られる。

$$
\dot{\boldsymbol{f}}=\boldsymbol{k}^{e}\left(\dot{\boldsymbol{u}}-\boldsymbol{h}\left\{\begin{array}{l}
\dot{\Omega}_{C} \\
\dot{\Omega}_{D}
\end{array}\right\}\right), \quad \boldsymbol{h}=\left[\frac{\partial \Phi^{c}}{\partial f} \frac{\partial F^{D}}{\partial f}\right] .
$$

$\dot{\Omega}_{C}, \dot{\Omega}_{D}$ は、式(43)から、節点变位速度の全成分により次のように 表される(式(43)左辺の係数マトリクスを $\boldsymbol{G}$ とする)。

$$
\left\{\begin{array}{l}
\dot{\Omega}_{c} \\
\dot{\Omega}_{D}
\end{array}\right\}=G^{-1} b^{T} \dot{u}, \quad b=k^{c} h
$$

これを式(46)に代入することにより、接線剛性 $\boldsymbol{k}^{e p}$.が得られる。

$$
\dot{f}=k^{e p} \dot{u}, \quad k^{e p}=k^{e}-b G^{-1} b^{T}
$$




\section{4. 数值計算フロー}

4.節で求めた塑性領域の広がりを考慮した等価モデルに基づき、 数值解析手順について説明する。基本的には Retum Mapping Algorithmに従うものである。時刻 $t$ における各諸量および時刻 $t+\Delta t$ における節点変位ベクトル ${ }^{t+\Delta t} \boldsymbol{u}$ が既知であるものとする。

〈單性予㨽子〉時刻 $t$ から時刻 $t+\Delta t$ に至る間で梁内部には塑性変形

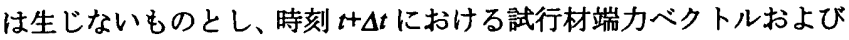
試行有効材端力ベクトルを求める。塑性変形が生じないと仮定して いるので、 ${ }^{t r} u_{p}={ }^{t} u_{p},{ }^{r} \theta_{p}={ }^{t} \theta_{p},{ }^{r} N^{c}={ }^{t} N^{c},{ }^{t r} M^{c}={ }^{t} M^{c}$ などが成り 立ち、試行応力および試行降伏関数は次のように求められる。

$$
\begin{aligned}
& { }^{r} N=k^{N}\left({ }^{t+\Delta t} u-{ }^{t r} u_{p}\right),{ }^{r} M=k^{M}\left({ }^{r+\Delta t} \theta-{ }^{t r} \theta_{p}\right) \\
& { }^{r} \Phi^{c}=\left|\frac{{ }^{r} N-{ }^{t r} N^{c}}{N_{Y}}\right|+\left(1-\frac{1}{2}{ }^{t r} \xi_{c}\right)\left|\frac{{ }^{r} M-{ }^{t r} M^{c}}{M_{p}}\right|-1
\end{aligned}
$$

ここで、この関数値が負であれば弾性仮定が正しく、正であれば弾 性仮定が正しくないことを意味する。後者の場合には次の塑性修正 子を実行する。

〈望性鹪正子〉增分間において何らかの塑性変形が梁内部に発生

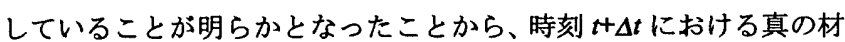
端力などは次のように表される。

$$
{ }_{(k+1)}^{t+\Delta t} N={ }^{t+\Delta(k)} N-k^{N}\left(\frac{\operatorname{sgn}\left({ }^{+}+\Delta t \tilde{N}^{c}\right)}{N_{Y}} \Delta \Omega_{C}\right)
$$

$$
\begin{aligned}
& { }_{(k+1)}^{i+\Delta t} M={ }^{t+\Delta \vec{k})} M
\end{aligned}
$$

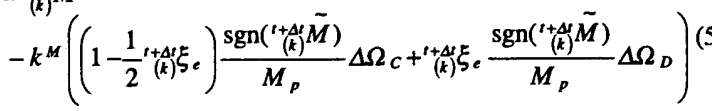

$$
\begin{aligned}
& \underset{(k+1)}{t+\Delta t} N^{c}={ }_{(t)}^{t+\Delta t} N^{c}+H_{u C C} \frac{\operatorname{sgn}\left(\begin{array}{c}
(+\Delta t) \\
(k)
\end{array} \tilde{N}^{c}\right)}{N_{Y}} \Delta \Omega_{C}
\end{aligned}
$$

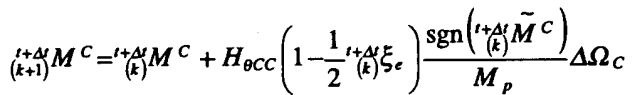

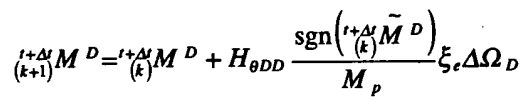

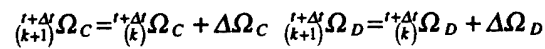

ただし、 ${ }^{t+}\left(\begin{array}{l}0 \\ 0\end{array}\right)={ }^{t r} N,{ }^{t+A f}\left({ }_{0}\right) M={ }^{t r} M$ などである。これらの表現を用いて時 刻 ${ }^{+}+\Delta t$ における ${ }^{++\Delta t} \Phi^{c},{ }^{++\Delta t} F^{D}$ を表わし、さらに、 ${ }^{1+\Delta t} \Phi^{c} \Rightarrow 0$, ${ }^{t+\Delta F^{D}} \Rightarrow 0$ とおくことにより、 $\Delta \Omega_{p}$ に関する連立方程式が得られる。

$$
\begin{aligned}
& \left\{\frac{k^{N}}{N_{Y}{ }^{2}}+\left(1-\frac{1}{2}{ }^{r+\Delta e}{ }^{(k)} \xi_{e}\right)^{2} \frac{k^{M}}{M_{p}{ }^{2}}+K^{T}\right\} \Delta \Omega_{c} \\
& -^{t+\Delta(k)} \xi_{e}\left(1-\frac{1}{2}{ }^{t+\Delta(k)} \xi_{e}\right) \frac{k^{M}}{M_{p}{ }^{2}} \Delta \Omega_{D}={ }^{t+\Delta}(k) \Phi^{c} \\
& -{ }_{(k)}^{t+\Delta \xi} \xi_{e}\left(1-\frac{1}{2}{ }^{t+\Delta f} \xi_{e}\right) \frac{k^{M}}{M_{p}{ }^{2}} \Delta \Omega_{C} \\
& +\left({ }^{+}+\Delta \xi_{(k)} \xi_{e}{ }^{2} \frac{k^{M}}{M_{p}{ }^{2}}+^{\prime+}+(k) \xi_{e}{ }^{2} \frac{H_{\theta D D}}{M_{p}{ }^{2}}\right) \Delta \Omega_{D}={ }^{l+\Delta}(k) F^{D}
\end{aligned}
$$

これを解くことにより、 $\Delta \boldsymbol{\Omega}_{C}, \Delta \boldsymbol{\Omega}_{D}$ が求められるので、式(52)を用 いて時刻 $t+d t$ における第 $k+1$ 近似解を算定更新する。更新された材 端力を用いて次式により ${ }_{(k+1)}^{t+\Delta t \xi}$ をを更新する。

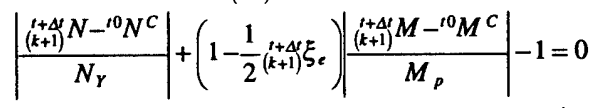

ここに、 ${ }^{10} N^{C},{ }^{10} M^{C}$ は弾性状態から降伏する段階での Back-stress であ る。以上の更新された值を用いて降伏関数の值を再度計算する。こ
の計算を ${ }^{t+\Delta t} \Phi^{c}{ }^{c}{ }^{t+\Delta t} F^{D}$ の值が許容值内に収束するまで繰り返す。

$$
\left|{ }^{t+\Delta} \Phi^{c}\right| \leq \text { Tolerance, } \quad\left|{ }^{t+\Delta t} F^{c}\right| \leq \text { Tolerance }
$$

なお、このように塑性領域の判定を塑性修正子の収束計算過程で 行う方法は、Multi-surface yield condition の場合を対象とした文献 3 における Simo らの第 2 の方法と概念的には共通する。ただし、塑 性修正子の収束計算過程において除荷負荷判定が困難となり、乡 值が振動する場合がある。特に界>1.5.においてこの傾向が強い。こ のような状況に陥った場合には、収束計算回数が 50 回を終了した段 階での $\xi_{e}$. 值を用い、これを定数としてこれ以降の収束計算を行う こととする。

\section{5. 等田モテルルの姦当性倹証}

本節では、前節で示した等価モデルによるひずみ硬化および塑性 領域の評価方法の妥当性および有効性について数値計算結果を通し て検証する。

Fig.6に解析対象を示す。硬化の影響を顕著にするために、硬化係 数は $E_{T}=E / 20$ と比較的大きな值としてる。載荷は $\mathrm{I}$ 節点の変位 $u, \theta$ を変位制御により行い、載荷条件は次の 3 種類を設定している。

Case-u15q1- $u: \theta=15: 1$ Case-u50q1- $u: \theta=50: 1$

Case- $\mathrm{u} 5 \mathrm{q} 1-u: \theta=5: 1$

また、本等価モデルの妥当性を検証するために、文献 5 で示した数 值積分点において弾塑性判定を行う梁要素を用いて解析した結果 (以下、FEM モデル) と比較する。直接の比較を可能にするために 増分間隔などは共通としている。等価モデルにおける収束判定值(式 (54)の Tolerance) は $10^{-10}$ としている。なお、FEM モデルでは梁全体 を 20 要素にて、要素等価モデルを用いる場合には 1 要素にて解析し ている。また、いずれの図においても、等価モデルによる結果をプ ロットで示し、FEM モデルによる結果を実線にて示している。

Fig.7 は、 $N-M$ 空間上での材端力の推移を比較したものである。3

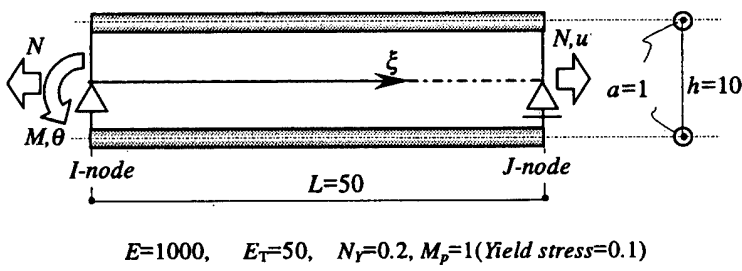

Fig.6 Two-flange model

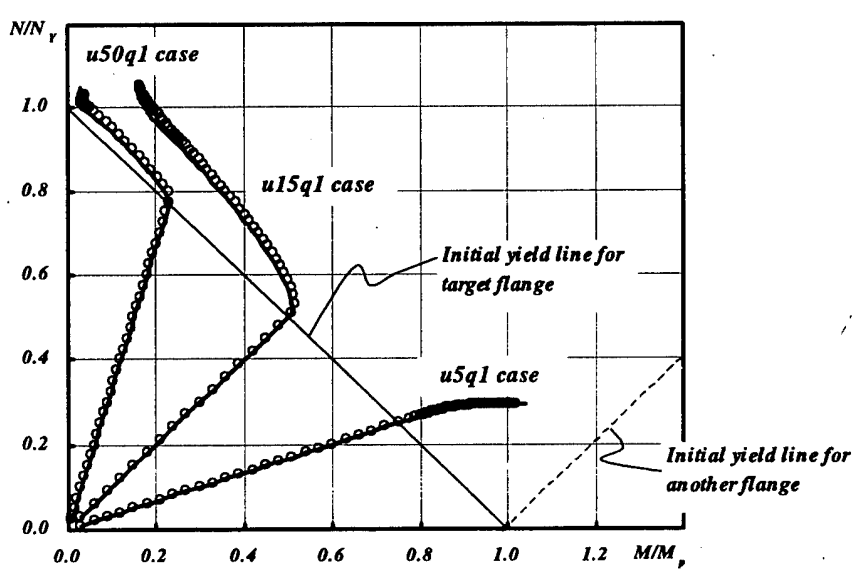

Fig. $7 N-M$ space 


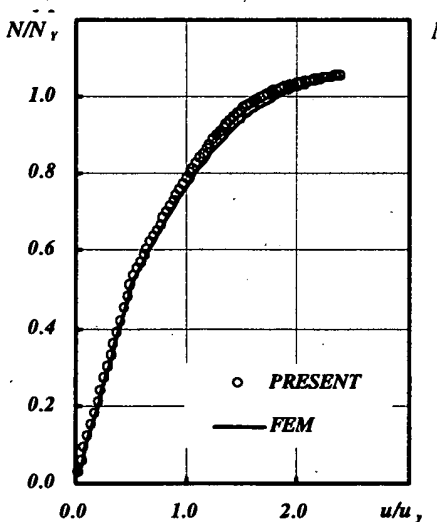

(a)

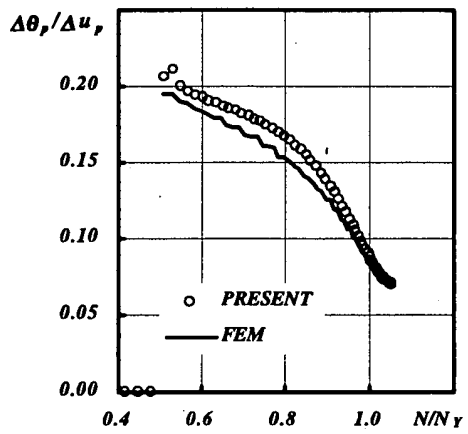

(c)

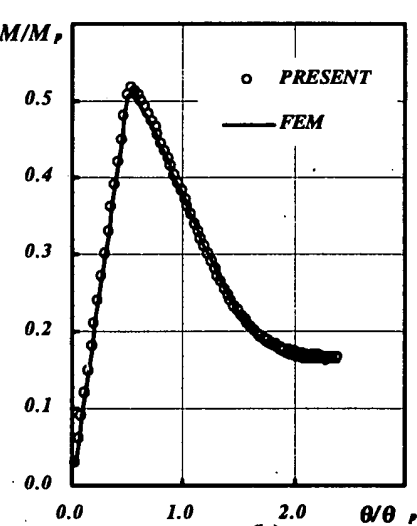

(b)

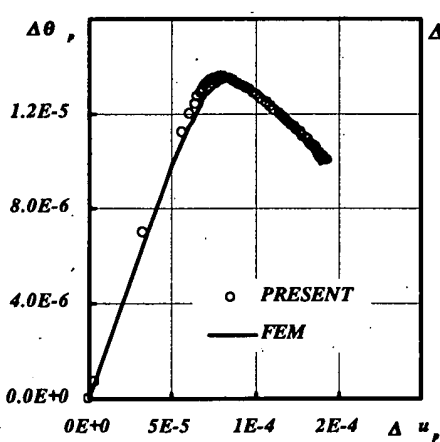

(d)

Fig. 8 Analytical results for Load case : $u 15 q 1$

節で述へたように、処女時の降伏線を越えた直後はほぼそれに直交 するように弾性的に推移している。その後、塑性領域が広がるにつ れ、見かけ上の硬化係数が小さくなり、処女降伏線にほぼ平行に推 移する様子が確認される。なお、いずれの結果も図中の破線（他方 フランジの処女降伏線）と交差しないことからも明らかなように、 これらのケースでは、上下フランジの塑性領域が分断されて生じる ことはなく、そのために式(32.d)を考慮する必要はない。

Fig.8〜10 は u15q1,u50q1 および u5q1 の載荷形式における(a) $N-u$ 関係、(b) $M-\theta$ 関係、(c)各ステップにおける $\Delta \theta_{p} / \Delta u_{p}-N$ 関係、(d)各ス テップにおける $\Delta \theta_{p}-\Delta u_{p}$ 関係を示す。荷重変位関係においては、 $M-\theta$ 関係において、降伏後急激にモーメントは低下するが、これ以外に 明確な折れ曲がり点は両関係において見られない。これも前述の $N-M$ 空間での材端力推移で述べた理由と同様、塑性領域が徐々に広 がり、硬化係数が連続的に变化するためであり、通常の塑性ヒンジ 法の結果と大きく異なる点である。各(c)および(d)の結果とも、等価 モデルと FEM モデルの結果はよく対応している。このことは、等 価モデルにおける塑性流れ則（節点変位塑性成分速度のベクトル方 向）およひ硬化則（同ベクトル長）に対する評価が妥当であること を意味している。

また、u15q1,u50q1 の結果では $N$ が $N_{Y}$ を越えた後も等価モデルと FEM モデルの結果はいずれもよく対応している。このとき、塑性領 域良は 1.0 を上回ることとなり、4 節で導いた等価モデルがこのよ うな場合にも有効であることを示している。

一方で、いずれの載荷形式においても収束に要した回数は、概ね、 降伏直後で 40 回、それ以外の区間で 20 回程度であった。さらに、 u50q1 では、 $\xi_{e}>1.5$ において 51 回（上限、ただし、 $\xi_{e}$ を定数とした 後の回数は 1 回)を要した。そこで、卢の更新を式(53)にて行わず、
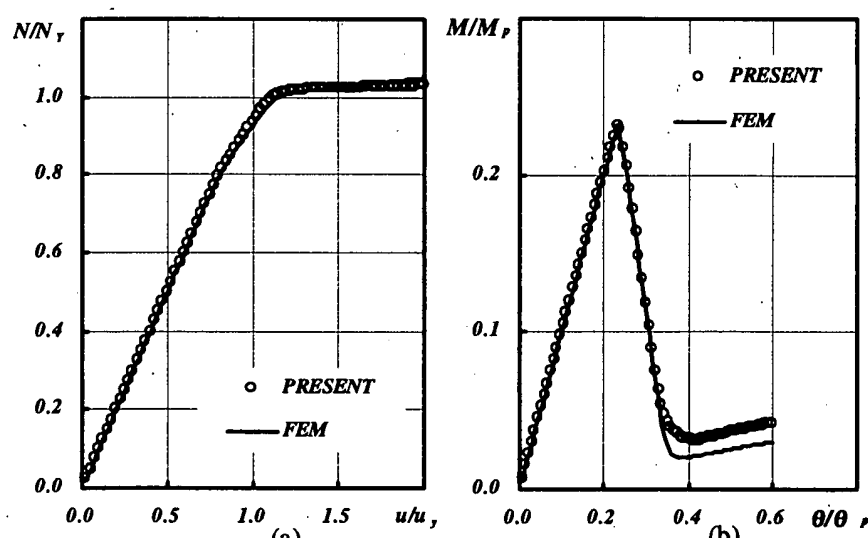

(a)

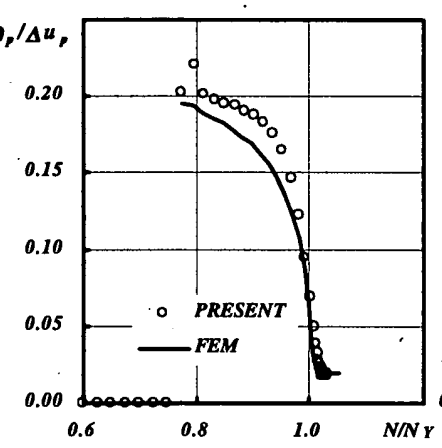

(c)

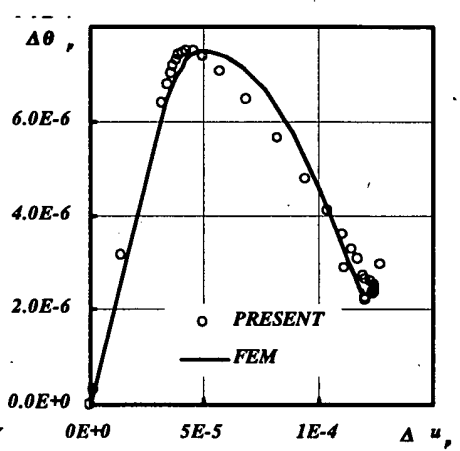

(d)
Fig.9 Analytical results for Load case : u50q1

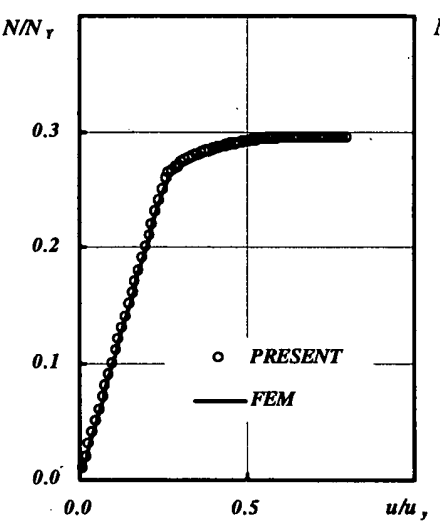

(a)

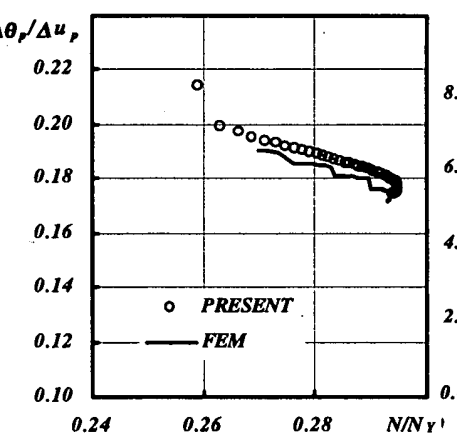

(c)

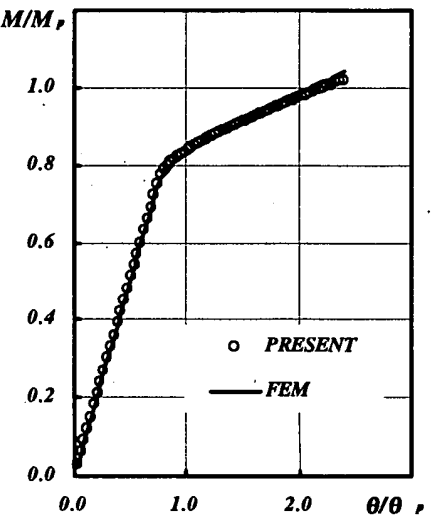

(b)

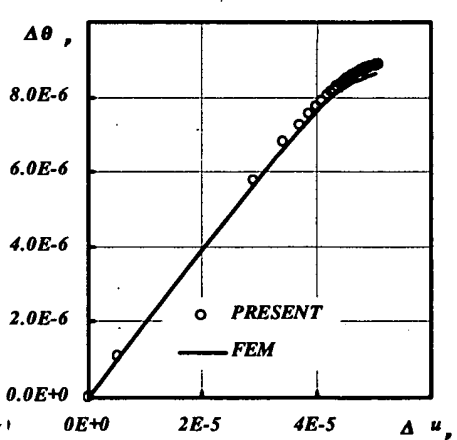

(d)
Fig. 10 Analytical results for Load case : u5ql

FEM モデルの結果から予め引 価モデルにより再計算する方法も試みた。この場合には、いずれの 場合も 2 回で目標精度に達した。したがって、式(53)による引 新方法が低い収束性の原因と考えられる。 


\section{6. まとめ}

本論文では、2 フランジ断面を有する梁要素の材端力-相対変位関 係に対する弾塑性構成則について新たな概念を提案した。すなわち、 2 フランジ断面から成る梁におけるひずみ硬化およびこれに伴う塑 性領域長を考慮した基䃈式を誘導するとともに、これを簡易に解く ことを可能にする実用的等価モデルの提示を試みた。また、提示し たモデルの塑性流れ則および硬化則に関して、有限要素法による結 果と比較することにより 3 節で設定した仮定 A,B,C を含む本提案手 法の妥当性を明らかにした。

ただし、本論文で定義した塑性領域長 $\xi_{e}$ がある程度大きな值とな った場合には、それ自体の一義的決定が困難となる問題点について も示した。この点に関するさらなる解決法については今後の課題と する。なお、本論文では、単調載荷下における 2 フランジ断面梁を 対象としたが、繰返し載荷および一般的な断面への本手法の拡張性 等については別報にて報告する予定である。

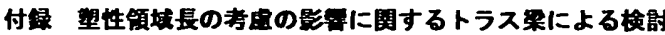

本論文で対象とする問題点を明らかにするために、Fig.A-1 に示すトラス 梁を弾塑性トラス要素を用いて解析した結果を以下に示す。各図には、 PEP モデル：すべての弦材を完全弹塑性体 HEP モデル：すべての弦材をひずみ硬化を有する弾塑性体 LEP モデル : 弦材(1),(13のみ HEP モデルと同様の弾塑性体

と設定した 3 種類のモデルに関する結果を示してある。これらは、HEP モ デルが塑性領域の広がりを考虐したモデルであるのに対して、LEP モデル は塑性領域の広がりを無視したモデル（従来の塑性ヒンジ法やマルチスプ リング法) に相当する。なお、上記指定以外の個材は弾性体としている。

Fig.A-2 は、 $N-M$ 空間上での材端力の推移を示したものである。図中の実 線は個材(1)〜9により規定される降伏条件に対応しており、図中の点 A,B,C,I は、 $(N, M)$ 推移線と個材(1),(2),(3),(9)により規定される降伏線との交 点である。これからも明らかなように、PEP モデルのように個材を完全弹 塑性体とする場合には個材(1)より規定される降伏条件のみが意味があり、 これ以外の条件はて長なものとなり意味がない。したがって、考慮すべき 材端力許容空間は、両端部上下に配される個材により規定される領域とな る。しかしながら、HEP モデルのようにひずみ硬化を考虑する場合には、 塑性領域が成長する過程で、個材(1)以外の個材により規定される条件も active となる（点B,C において、それぞれ個材(2)，(3により規定される条 件が active となる)。つまり、個材がひずみ硬化を有する場合には、塑性領 域の進展に伴い、材端力許容空間の形態は姿化することとなる。この特性 は、本モデルの硬化則が等方・移動硬化則では表現出来ないことをただ示 すのではなく、塑性流れ則を考える場合の基準となる降伏関数のあり方が 変化することを意味し、塑性変位成分の速度方向が著しく変化すること意 味する。Fig.A-3(a)(b)は節点力-節点変位との関係を示したものであり、HEP モデルと LEP モデルの比較から、個材(2が降伏する点 B までは両者の結果 は一致するものの、点 B 以降において、塑性領城の広がりを無視する LEP モデルの結果は、HEP モデルとかなり異なる結果となっている。この原因 は、LEP モデルでは、上述した節点変位の塑性成分速度方向を正確に評価 し得ないためである。これを具体的に示したものが Fig.A-4 である。PEP モデルおよびLEP モデルともに、個材(3)が降代するまでは、個材(1)より 規定される降伏条件のみが active であるために、 $\Delta \theta_{p} / \Delta u_{p}$ は材端力の変化に 関わらず一定の値となっている。これに対して、HEP モデルの結果は、塑 性頒域の広がりに伴い、 $\Delta \theta_{p} / \Delta u_{p}$ は小さな值に変化する。以上より、ひずみ 硬化を考える場合には塑性領域の広がりを考虑した手法によらなければな らないことは明らかである。なお、点 C,I における塑性進展パラメータ総 量（実線）および增分量（破線）の分布を Fig.A-5 に示寸。この結果から 本論 3，1 項で設定した仮定 A,B の適切さは明らかである。

参考文献

1. まとめられたものとして、忘用力学シリーズ 4 構造物の崩壊解析基磷編 4.1 節およひ 4.2 節、日本建築学会、1997

2. 瀧口、西村 : 構造物の二次元非線形復元力特性と塑性論との類似性、日 本建築学会構造系論文集、第 525 号、pp.85-91、1999

3. J,C,Simo, et.al : Non-smooth multisurface plasticity and viscoplasticity, Int. J. Numer. Meth. Engng., vol.26,pp.2161-2185, 1988

4. N.R.Hansen, et.al. :A thermodynamically consistent frame work for theories of elastoplasticity coupled with damage, Int. J. Solids Structures, vol.31, No.3, pp.359-389, 1994

5. 白、元結 : そり変形の影䧸を考虑した梁要素による平行弦トラス梁から 成るラチスシェルの数值解析に関する一考察 その 2 弾塑性座屈挙動 人の展開 日本建築学会大会学術講演梗概集構造 I、pp.805-806,2001

6. 元結、大塚 : 塑性論に基づくトラス梁の弾塑性問題に対する解析手法の 提案、日本建築学会構造系論文集、第 538 号,pp.109-114、2000,12

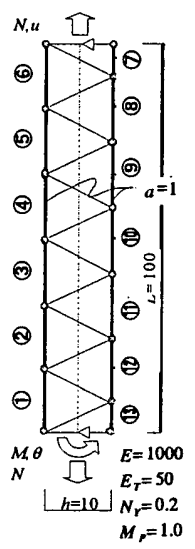

Fig.A-1 Truss girder

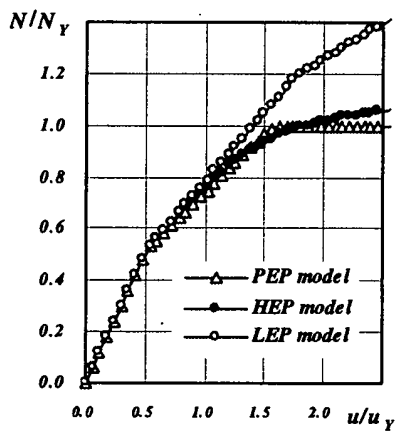

(a) Axial force-stretch relation Fig.A-3 Load-displacement curve

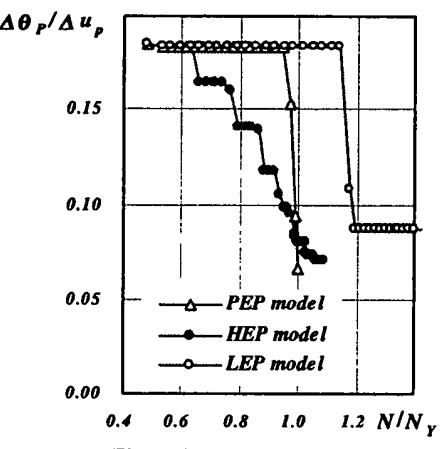

Fig. A- $4 \Delta \theta_{P} / \Delta u_{p}-N / N_{Y}$ relation

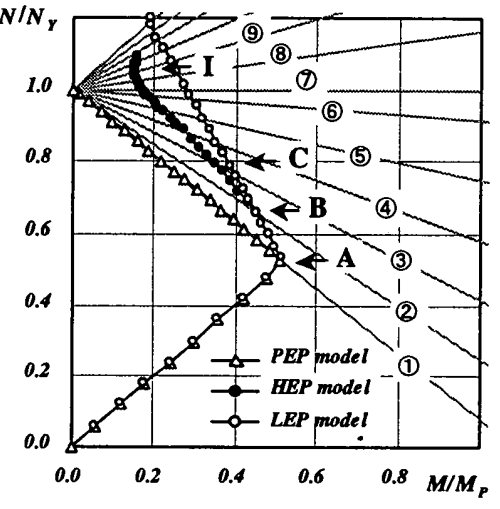

Fig.A-2 $N-M$ space

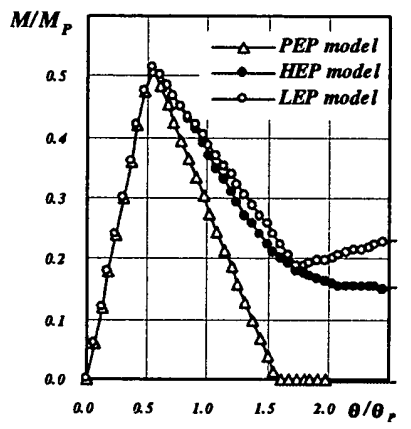

(b) Moment-rotation relation

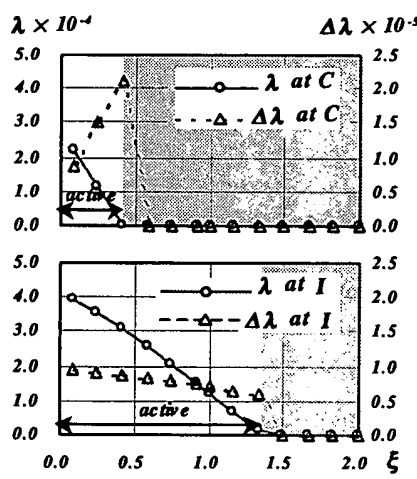

Fig.A-5 Plastic parameter (HEP model) 